\title{
JESUS THE 'TEACHER-SAVIOUR' OR 'SAVIOUR-TEACHER': Reading the Gospel of Matthew in Chinese contexts
}

Author:

John Y.H. Yieh ${ }^{1,2}$

Affiliations:

${ }^{1}$ Virginia Theological

Seminary, Alexandria, USA

${ }^{2}$ Department of New Testament Studies,

Faculty of Theology,

University of Pretoria,

South Africa

Correspondence to:

John Y.H. Yieh

e-mail:

jyieh@vts.edu

Postal address:

Virginia Theological

Seminary 3737 Seminary

Road Alexandria, VA

22304, USA

\section{Keywords:}

Gospel of Matthew;

Christology; Chinese

biblical hermeneutics;

Taiping Kingdom;

cross-cultural

interpretation

\section{Dates:}

Received: 08 Jan. 2009

Accepted: 06 July 2009

Published: 11 Nov. 2009

How to cite this article:

Yieh, J.Y.H., 2009, 'Jesus

the "teacher-saviour" or

"saviour-teacher": Reading the Gospel of Matthew

in Chinese contexts', HTS

Teologiese Studies/Theology

Studies 65(1), Art. \#317, 10

pages. DOI: $10.4102 /$ hts.

v65i1.317

\section{This article is available}

at:

http://www.hts.org.za

\section{Note:}

Prof. Dr John Y.H.

Yieh participates in

the research project

'Biblical theology and

hermeneutics' directed

by Prof. Dr Andries G.

van Aarde, Honorary

Professor of the Faculty of

Theology at the University

of Pretoria.

(C) 2009. The Authors. Licensee: OpenJournals

Publishing. This work

is licensed under the

Creative Commons

Attribution License.

\section{ABSTRACT}

While every interpretation is culturally particular and context-specific, the critical assessment of the hermeneutical principles and social consequences of real examples from different cultures may facilitate fresh readings of the scripture with more creative imagination, theological integrity and ethical responsibility. This essay investigates three influential interpretations of Matthew's Gospel by well-known Christian leaders in China: Hong Xiuquan, Wu Leichuan and Watchman Nee. Different theological orientations notwithstanding, they all highlight Jesus' role as 'saviour and teacher' and favour the Sermon on the Mount. The strategies that they use to appropriate Matthew's Gospel and to make Jesus relevant show what it takes to ensure a sound hermeneutical process. They also bring to the table of Matthean scholarship insight into the roles that Jesus plays in the Gospel narrative and in various socio-cultural settings. Finally, they provide interesting cases for a brief reflection on cross-cultural readings and post-colonial criticism that have fascinated recent biblical scholars.

\section{INTRODUCTION}

Reading the Gospel of Matthew in global contexts with critical hermeneutical reflection may reward the reader with benefits similar to those that a Wirkungsgeschicht approach can garner from the examination of influential interpretations in the past and from the assessment of their historical effects in the Western interpretative tradition, in other words horizon-broadening and self-correcting (Luz 1994:23-38, 2005:333-369). When we study the reception history of Matthew diachronically through history and synchronically across cultures, much can be learned about sound exegesis and the ethical appropriation of the scripture, if we recognise that, while every interpretation is culturally particular and context-specific, some historical examples and fundamental principles in hermeneutics can be critically observed, assessed and applied to facilitate fresh readings of the scripture with creative imagination, theological integrity and ethical responsibility.

This paper attempts to investigate three contextual interpretations of Matthew's Gospel by well-known Christian leaders in China. These influential leaders could not be further apart from one another in theological conviction and political position but, remarkably, all of them see Matthew's Jesus playing the combined role of saviour and teacher and all focus their expositions on the Sermon on the Mount. My first goal is to find out why Christology and ethics in Matthew are favoured by Chinese readers, how these are appropriated in different cultural and social contexts and what impact they exert on their readers. Answers to these questions may give us new lenses through which to see Matthew's Jesus afresh. These Chinese readings of Matthew also provide fascinating examples of minority hermeneutics to show how the Christian Bible, with no claim to authority among Chinese people, justifies its usefulness and has its voice heard in a multi-religious and multi-scriptural society in the last two centuries.

Finally, these readings raise interesting questions about finding scriptural meaning in cross-cultural settings (West versus East) and in colonial and post-colonial discourses. A hermeneutical reflection may open a new window for us to look through and to appreciate the cultural assumptions and social contexts of Chinese people, a huge population in the global South, and ponder how Matthew may yet speak to them.

\section{READING MATTHEW IN CHINA}

The Gospel of Matthew was first translated into Chinese by Joshua Marshman of the Serampore mission in Calcutta and his assistant Johannes Lassar and published in Serampore in 1810. Chinese readers had to wait until 1814, however, to see another version of this in the Chinese New Testament. This version was translated and published by Robert Morrison of the London Missionary Society. Morrison's translation was carried out in Canton and Malacca with the help of Chinese assistants and it was therefore widely accepted, becoming the basis of later revisions and versions (Loh 1995:55). In the short history of Protestant Christianity in China, three distinctive readings of Matthew and their particular views of Jesus are worthy of scrutiny. Significantly, all three share a focus of interest on Jesus' inspiring personality and moral teachings.

\section{Hong Xiuquan (1814-1864): Jesus the saviour as law-giver}

One early Chinese convert to Protestant Christianity was Hong Xiuquan, the famous rebel king of Taiping Tianguo ('the great peace kingdom of heaven'). Born into a poor family in Guangxi province, Hong studied Chinese classics, hoping to pass the civil examination so that he could obtain a government job. He tried many times but failed. He once fell so ill that he was on the brink of death and it was then that he saw a series of visions in which he was taken up to the heavenly court to meet with a dignified bearded old man. After reading a Christian pamphlet written by Liang A-fa, one of Morrison's Chinese assistants, Hong came to believe that the old man whom he had seen during his visions was God and that Jesus was his elder brother and he himself was the second son of God. He also came to believe that he had been sent to this world to fight demons. He therefore baptised himself and gathered a group of 
followers called Baishangdihui ('the society of the worshippers of God'). Because of its iconoclastic zeal and frequent conflicts with Confucian scholars and Buddhist believers, Hong's 'Christian' group was suppressed by the authorities and consequently turned into a rebel force against the Qing government. Despite military struggles, hundreds and thousands of hungry peasants were attracted by the loving care, gender equality and strict discipline of this group and joined it. Three years later and, quite miraculously, the group established a new kingdom in Nanking (in 1850), occupying half of the nation south of the Yangtze River, including some of the richest provinces and regions.

The impact of Matthew's Gospel on Hong is immediately clear in the naming of his kingdom as Taiping Tianguo ('the great peace kingdom of heaven'), in which the peculiar Matthean phrase 'kingdom of heaven' is used. With visionary dreams and military successes made sense by an idiosyncratic reading of the Bible, Hong constructed an apocalyptic belief system and became convinced that, as the second son of God, his mission was to establish God's heavenly kingdom, which his elder brother, Jesus, had ushered in, among the Chinese (Wagner 1982). This is why Jonathan Spence, a Yale historian, called him 'God's Chinese son' (Spence 1996, 1998:9). In his capital city, Nanking, which Hong called 'little paradise', he erected a monument of the Beatitudes to make a political statement to the effect that the blessings announced by Jesus in his Sermon on the Mount were fulfilled in Hong's kingdom. The monument begins with the words 'Heavenly elder-brother Christ saviour of the world says ...' and is followed by the beatitudes taken from Matthew 5:3-11 (Jenner 1911:37)

In 1853, Hong Xiuquan published a New Testament with his own annotations entitled Qinding qianyizhao shengshu ('The sacred book of the formerly bequeathed oracles [former testament] annotated by his Royal Majesty'), a copy of which is preserved in the British Library in London (British Library, Asian and African Reading Room, 15117.e.19; see also Luo \& Wang 2004:113-150 Michael 1966:227-229). In this Bible, we find three repeated themes in Hong's usually brief comments on select texts in Matthew's Gospel. These will now be discussed.

\section{Jesus as the Son of God}

In the upper margin of 2:15ff, ${ }^{1}$ for instance, Hong wrote 'Isaiah proves that Jesus is the Son of God, so declares the Emperor'. Other similar comments include 'The demons recognise the Princely Brother as the Son of God, so declares the Emperor' (8:29), 'The Princely Brother proves himself to be the Son of God' $(10: 32,37)$, 'Both the Princely Brother and his disciples prove Christ to be the Son of God, so declares the Emperor' (16:16) and, again, 'The voice from the clouds announces Christ to be the Son of God. It is evident, then; so declares the Emperor' (17:5). Hong also noted how Jesus 'descended from heaven to the world' $(3: 11 ; 10: 34)$ and, with God the Father's presence, was able to cast out demons, eliminate evil powers $(10: 34 ; 13: 37)$ and perform healing miracles $(8: 2,15 ; 9: 29)$. Moreover, Jesus Christ revealed God's will by giving prophecies ('The Princely Brother declared in advance that the kingdom of heaven had come near, and now it has' [5:17]), by teaching plainly ('the Princely Brother announced that he preferred mercy to offering' [9:13]) and by using metaphors to reveal that the emperor was the sun and the queen was the moon (24:29) and that Hong himself would be the Lord to rebuild the destructed temple of God (27:40). These comments in the upper margins demonstrate that, for Hong, Matthew's Gospel provided significant scriptural evidence to prove that Jesus Christ, his Princely Brother, was indeed the Son of God. They also indicate Hong's belief in Jesus' divinity as a mighty saviour who came to the world to rescue his people from all kinds of demons, idols and tyrants and in Jesus' authority as an esoteric revealer who could foretell the mystery of the kingdom of heaven.

1.All the references in this section refer to the beginning of a pericope in Matthew. Hong wrote his annotations on the upper margin of the running text.
The fulfilment of Jesus' prophecies

In several comments, Hong called attention to the fulfilment of Jesus' prophecies in his Taiping kingdom with the words 'Jesus said . . . It is now fulfilled; so declares the Emperor'. For instance, the heavenly kingdom that was approaching had been realised on earth (5:17), the demons - referring to the corrupt Qing officials - had been defeated (10:34), the righteous were enjoying the blessings in the kingdom of the heavenly Father (13:37) and the Princely Brother had returned to earth to gather peoples from all directions into the Taiping kingdom (24:29), who received his glory in Hong's palace (25:31). These pesherlike comments may easily be condemned as 'eisegesis' but, to Hong and his followers, they related Matthew's text to their life experiences with amazing credence. In fact, with the 14 so-called formula or fulfilment quotations of Old Testament prophecies in the First Gospel, Matthew may have provided Hong with clear examples to make the same interpretative move. Not unlike the Qumran pesherim and Matthew's Old Testament quotations, the argument of prophetic fulfilment functioned to legitimate the Taiping rebels' self-identity and boost their confidence as they struggled to accomplish their military missions to defeat what they called 'Qing demons'.

\section{Hong's role in God's plan}

It is fascinating to see how Hong used Matthew as God's authoritative word to prove his claim as the second son of God and therefore his legitimacy to the throne of the Taiping kingdom. In the upper margin of 4:1ff, Hong wrote the following:

God is fire. The Sun is also fire, so God and the Sun come together. So declares the Emperor. ... God is fire, so God has divine light; the Princely Brother is fire, so he is the great light; the Emperor is the Sun, so he is also the light. So declares the Emperor.

(Qinding qianyizhao shengshu ['The sacred book of the formerly bequeathed oracles [former testament] annotated by his Royal Majesty'], top margin of Mt 4:1)

In 4:15-16, Matthew quoted Isaiah 9:1-2 - 'The people who sat in darkness have seen a great light' - to show that Jesus' moving from Nazareth to Capernaum by the sea of Galilee 'in the territory of Zebulun and Naphtali' fulfilled another messianic prophecy (4:14). This quotation may have prompted Hong to comment on God the divine light, Jesus the great light and he himself the sun and to say that all of them bring light to the dark world to give it new life and hope. Why did Hong consider himself the sun? This may have come from a fantastic reading of his name in Chinese onomatology (the study of the significance of personal names in Taoist tradition). In a comment on 27:40, which describes onlookers at the scene of the crucifixion deriding Jesus, saying, 'You who would destroy the temple and build it in three days, save yourself', Hong wrote the following:

Hong [洪; his last name in Chinese writing] has three dots [on the left side of the Chinese word] and three days [for Jesus to rebuild the temple; 三日, in Chinese, also means 'three sun'] means Hong Sun. [Thus,] the Princely Brother implies that Hong as the sun shall be the Lord to rebuild the destroyed temple of God. So declares the Emperor.

(Qinding qianyizhao shengshu ['The sacred book of the formerly bequeathed oracles [former testament] annotated by his Royal Majesty'], top margin of Mt

This onomatological comment probably made no sense to others but himself and his loyal followers but, again, this interpretative strategy resembles the esoteric interpretation of the Qumran pesherim and involves a Chinese interpretative tradition that uses hidden meanings in and associations with names and symbols. Believing himself to be the sun, which gives life to the Earth, the sun being an important symbol for Chinese people living in an agricultural society, Hong also commented on 24:29, where Jesus talked about the frightening change of the natural signs at the end of the age after the suffering days and before the coming of the Son of Man: 
The Princely Brother was concerned not to let loose the secrets, so he gave an implicit teaching saying that the Emperor is the Sun that turned dark when becoming a human on earth, and the Queen is the Moon that does not shine when becoming a human on earth.

(Qinding qianyizhao shengshu ['The sacred book of the formerly bequeathed oracles [former testament] annotated by his Royal Majesty'], top margin of Mt

Hong believed that he was the second son of God, formerly living in the heavenly court with God the Father and Jesus his elder brother. He believed that he had been sent to earth through incarnation on a mission to defeat the brutal Qing government and to save his people from oppression. When he had gathered suffering people from all places into his Taiping heavenly kingdom, Jesus' prophecy of the coming of the Son of Man had been fulfilled. The kingdom of heaven had been realised on earth in China.

Hong's reading of Matthew was esoteric, sectarian and indeed personalised. It was obviously not a systematic exposition of the Gospel's text or of Matthew's intention but a series of random comments on select passages to present Hong's view of Jesus on behalf of his Taiping heavenly kingdom. This use of text does highlight one of Matthew's Christological emphases on Jesus as the 'Son of God' that most critical scholars in the West can accept (Kingsbury 1975). Hong also imitated Matthew's use of the prophecy-fulfilment argument to prove Jesus' messianic identity. By claiming that Jesus' eschatological prophecies were fulfilled in his Taiping kingdom, he wished to legitimate his own identity as God's second son and his divine mandate to rule over the new kingdom. To insert himself in Jesus' prophecy of the sun at the end of time, as noted previously, he also adopted a Taoist onomatological interpretation. Hong's pesher-like interpretation of Matthew was prompted and emboldened by the many miracles that he experienced in sickness and in military campaigns. To him, Matthew's Gospel was undoubtedly a divine and heavenly book that revealed God's plan and authenticated his role as king. This legitimation, in turn, gave him absolute authority to rule over his people with strict laws and severe punishment. He may be called a 'Chinese Constantine', who built a 'Christian' kingdom in China for 14 years.

In the excitement of his early success, the British and Foreign Bible Society in London ran a successful campaign - 'One million Bibles for China' - which excited and mobilised women's clubs as well as Sunday-school children to raise two and half times the estimated budget in just four years. In China, Hong's rebellion against the Qing dynasty inspired Sun Yat-sen to finally overthrow that brutal regime and to establish the first republic in Asia (in 1911). Mao Tzedong, leader of the Communist Party, also hailed Hong's Taiping movement as a great success and model of his peasants' revolution that sought to bring justice to the downtrodden social classes. Looking back on the history of Taiping Tianguo, however, the consequences of Hong's selfappointment as God's second son and the loss of twenty million more lives throughout his ruthless rule by biblical law cannot but raise eyebrows and a huge red flag about the appropriateness of his biblical interpretation. The scripture may indeed speak to believing individuals in various cultural, historical and social settings but is there any sort of critical apparatus that the community of faith may use to discern the validity and appropriateness of individual interpretation? Evidently, the historical-critical reading of the Bible being developed in Europe had not found its way to China during this time. Without much help from missionaries, Hong read the Bible as a heavenly book that spoke to him personally and his own concerns for selfidentity and purpose in life became the only lens through which the Bible was read.

\section{Wu Leichuan (1870-1944): Jesus the teacher as social reformer}

Just as Hong Xiuquan considered the 'kingdom of heaven' the central theme of Matthew's Gospel, so did Wu Leichuan, a
Christian leader with scholarly expertise in Chinese classics. In contrast to Hong, however, who regarded Jesus as the Son of God who came to save his people from the oppression of tyrants, $\mathrm{Wu}$ honoured Jesus as a wise sage who inspired his followers by example and word to cultivate their moral character in order to build an ideal society of self-sacrifice and love. Whereas Hong's view of the kingdom of heaven was military and political, $\mathrm{Wu}^{\prime} \mathrm{s}$ was moral and social.

Wu Leichuan was a prominent scholar of Confucian classics and the first Chinese chancellor of Yenching University (Chu 1995; West 1974:226-246). Converted to Christianity at a mature age, $\mathrm{Wu}$ began to read the Bible fastidiously, and published several well-acclaimed books on Christianity and Chinese culture and hundreds of essays on the subjects of faith, education and public service (Malek 2004:533-538). Wu's writings were influential among educated elites in Chinese universities. He provided an indigenised version of Christian faith at a volatile time when nationalism (protest against Western imperial ambitions and corrupt officials), the May Fourth Movement (an intellectual movement for socio-political reform) and the Non-Christian Alliance (an anti-Christian student coalition) were boiling over in major universities (Chow 1960).

Wu argued that only Jesus' moral character - not doctrines or liturgies of the church - were to be considered the essence of Christianity and that Jesus' teaching was meant to guide his followers to obey the truth and reform society (Wu 1936:10). Separating Jesus the moral sage from the institutionalised church and Western colonial powers was an important idea that helped $\mathrm{Wu}$ to survive, both intellectually and spiritually (Wu 1924a, $1924 b, 1931,1936: 10)$, the attacks and challenges of the fierce anti-Christian movements dominating Chinese universities in the early 20th century.

\section{Jesus as wise sage}

Who then was Jesus? In Wu's reading of the Gospels, Jesus emerges as a messianic revolutionary turned wise sage of the kingdom of heaven, who dedicated his life to establishing an ideal society by teaching his followers to cultivate moral character and to affect the renewal of moral virtues. In terms of Chinese culture, Jesus was Shengtianzi ('the holy Son of God'), who had heavenly wisdom to teach the world as a sage-king (Wu 1936:82-98). Jesus' miracles were, in fact, largely neglected or interpreted from a rationalist view to extract moral lessons. The miracle of feeding the five thousand, for instance, was interpreted as a miracle of a selfless love of the boy that inspired the large crowds to share the food that they had brought with them rather than a supernatural act of multiplying five loaves and two fish.

It was by emulating Jesus' compassion for the poor and willing self-sacrifice and by sincerely obeying his teachings and commandments that Christians could reform their Chinese culture and save their weak nation from demise under Western imperial exploitation and the self-destruction of civil wars. This was why Jesus could be useful to the Chinese, $\mathrm{Wu}$ argued: Jesus the teacher had a universal moral wisdom that could change human hearts and reform a society from the inside out. By perfecting moral character first, Chinese people could then make good use of scientific knowledge and patriotic spirit to build a new China and finally bring freedom, equality and prosperity to all people, hence the idea of renge jiuguo ('saving the nation by moral character'). Underlying this argument was the traditional Confucian doctrine of neisheng, waiwang ('become a sage inside and then rule as a king outside') and the deep-rooted pedagogy for moral formation: xiushen, qijia, ziguo, pingtianxia ('cultivate personal character, order family life, govern national affairs and bring peace to the world').

The kingdom of heaven that Jesus proclaimed, Wu argued, was not a paradise in heaven beyond death but an ideal society that could be established in the present world where freedom, equality and charity were enjoyed by all peoples (Wu 1925). To explain 
the idea of the kingdom of heaven, Wu cited Jesus' words from all four Gospels, albeit mostly from Matthew, for discussion. He argued that Jesus' total commitment to the kingdom of heaven came from a strong sense of divine calling and that Jesus started his ministry with a political plan to build a heavenly kingdom in Palestine for Jewish people under the brutal oppression of the Romans. When his partner, John the Baptist, was executed by Herod and his efforts were thwarted by mounting opposition from Jewish leaders, $\mathrm{Wu}$ surmised, Jesus came to the realisation that he had to revise his political plan to focus on a spiritual one. He therefore changed direction first to seek to transform the hearts of his followers by word and example, even if it meant that he had to sacrifice his life to provide an inspiration for them. Only when people's hearts were transformed, Wu argued, could a corrupt society be cleansed and the kingdom of heaven realised on earth. The kingdom of heaven was therefore an ideal society in which old concepts were changed and old organisations were reformed so that boundaries no longer existed between nations and races. It was also a new society without economic disparity that separated the fortunate from the suffering, without private ownership that encouraged greed and competition and without a shortage of provisions because everyone shared both work and joy (Wu 1936:66-72).

\section{The Sermon on the Mount as a social program}

Wu Leichuan read Matthew, the Sermon on the Mount in particular, as a manual for a social program meant to implement Jesus' kingdom of heaven on earth. Three points can briefly be commented on as examples:

- To emphasise the importance of reforming one's heart, $\mathrm{Wu}$ cited Matthew 5:17 to illustrate that Jesus came to the world for the purpose of fulfilling God's law. As testified in the socalled antitheses (Mt 5:21-48), God would not judge people according to their visible behaviour but according to their secret motivation. For instance, he who became angry with his brother would be judged as a murderer and he who looked at a woman with lust had committed adultery. Jesus therefore warned his audience to take precautions with their hearts. He admonished them not to give alms, pray or fast for vain glory because God would not be pleased by hypocrisy. Thus, Wu argued, to enter the kingdom of heaven as an ideal society, one needed to begin with a change of heart (Wu 1950:299-300).

- Wu highlighted Jesus' exhortation not to concern themselves with food or clothes but to strive first for the kingdom of God and for his righteousness (Mt 6:33). This did not condone laziness, $\mathrm{Wu}$ explained, but rather urged people to make an effort to reform their lives as a community so that the ideal society that God had planned could be established on earth in which everything would be done according to God's righteousness. When people concerned themselves with food and clothes and fought with each other for life provisions, they lived in anxiety and found no happiness. If, however, people sought first to realise the kingdom of God, which called for equality and love, people would be able to work hard and be willing to share. It was then that an ideal society would be formed (Wu 1950:294).

- Wu upheld the Lord's Prayer as the blueprint for the building of the kingdom of heaven (Wu 1950:302-304). He maintained that this was cited from Luke 11:1-4, although the text was actually quoted from Matthew 6:9-13. In the Chinese Bible that $\mathrm{Wu}$ used, the longer and more familiar Lord's Prayer in Matthew's version was printed in Luke 11:1-4 to replace the shorter Lukan version. Wu did not seem to be aware of the translator's intention to avoid confusion for the reader.

Wu considered the address to God as 'our Father who art in heaven' an important reminder that all peoples were children of God and that we should therefore love one another as brothers and sisters in a big family. According to $\mathrm{Wu}$, the familial relationship is the basic and necessary condition for success in building the kingdom of heaven as an ideal society. The first divine petition - 'hallowed be thy name' - teaches us to obey God's truth and justice. 'Thy kingdom come' means replacing hatred and injustice with mercy and justice to enable the kingdom of heaven to come. 'Thy will be done' is a desire to ensure that society could be reformed despite resistance. The first human petition - 'give us this day our daily bread' - teaches us to be equal-minded and without greed, that we should ask only what is needed. The forgiveness petition teaches us to receive peace of mind from God and from each other by mutual forgiveness. Finally, the petition 'do not lead us into temptation, but deliver us from evil' requests divine help to overcome temptation and eliminate disaster. By enlisting the principles of the kingdom of heaven in a prayer for the whole community of faith to recite ritually, $\mathrm{Wu}$ argued, Jesus wanted to ensure that his followers worked together with one mind to build an ideal society.

\section{Wu's biblical hermeneutics}

Wu's theologically liberal and socially progressive interpretation of the scripture showed similarities and affinities with the Protestant liberalism of Germany in the late 19th century and the Social Gospel Movement of America in the early 20th century, both of which found their way to China through translations of books and through missionary teachers, as Wu Yaozong (1936:5) pointed out. The rationalistic approach to biblical interpretation made good sense to $\mathrm{Wu}$ Leichuan (1936:3-8) as a scholar because he believed that religion was a driving force for social evolution; as such, religion should also evolve with time and work with science and a progressive religion should focus on philosophy of life to reform human society.

It is significant to note that $\mathrm{Wu}$ was keenly aware of the Western imperialism that was robbing the pride as well as the land of the Chinese people. He did not, however, look for a mighty saviour in Jesus to save China from colonial power, as Hong Xiuquan had. Instead, he saw political corruption and social malaise as mere symptoms. It was the moral bankruptcy in each citizen and in the national leaders that was the root of all problems. This was a typical Confucian view of social ills. Seeing Jesus as a supreme teacher who could reform Chinese society through moral teaching reflected another Confucian conviction. This held the basic goodness of human nature, which could be transformed through effective moral education and which, through individual moral character, could ultimately save a country through the removal of corruption, greed and injustice in human hearts. In Wu's reading of Matthew, there was a remarkable mixture of Western rationalism and Chinese moral approaches. Evidently, Wu did not see Chinese culture as an enemy or rival to Christian faith. Neither had Jesus come to China to abolish Chinese culture; he had come instead to fulfil it. Wu's effort to interpret Jesus and his kingdom of heaven in Chinese terms became one of the earliest and best examples of indigenisation.

Wu's view of Jesus as an inspiring moral sage found loud echoes among the Chinese literati of the first half of the 20th century. One of the most renowned supporters of this view was Chen Duxiu (1879-1942), an influential professor and a founding leader of the Chinese Communist Party, who called Jesus the 'incarnation of universal love' (Chen 2005:1208-1214). Many Chinese church leaders educated in the West according to a liberal theological perspective held the same view of this biblical interpretation in general and of Matthew's Jesus in particular. Wu Yaozong (1893-1979), leader of the YMCA and the Three Self Patriotic Movement, confessed that he was converted to Christianity by nothing other than the awe-inspiring Sermon on the Mount in Matthew 5-7 (Wu 2005:1236-1241). Ding Guangxun (Bishop K.H. Ting, 1915-), long-time leader of the Protestant Church in China, insisted on preaching Jesus as the cosmic Christ who revealed God's love to all people, both believers and non-believers (Ding 2000). This trajectory was a strong indication of Wu Leichuan's influence among some Chinese Christian leaders.

Watchman Nee (Ni Tuosheng, 1903-1972): Jesus the saviour as seelsorger (spiritual director)

Contrary to Wu Leichuan's reading of Matthew as a historical 
text providing information about Jesus the sage and his teaching of an ideal society, Ni Tuosheng, better known as Watchman Nee, read Matthew as a revelatory text that presented Jesus as the Son of God, whose mission was to save his people from sin and to provide guidance for their spiritual life.

Watchman Nee was the charismatic founder of a major independent church, the 'Local Church', nicknamed 'Little Flock'. He was well known for his eloquent preaching and his adept teaching of spiritual theology and biblical studies (Kinnear 1974). After the Communist takeover, Nee refused to sign the socalled 'Christian manifesto' (in 1950), which demanded church leaders to pledge allegiance to the new government. Under intense political pressure, however, Nee's churches decided to participate in the so-called 'accusation sessions' to show their compliance with the new religious policies.

Nee was nevertheless arrested but his imprisonment only added to his stature and influence among his followers, some of whom had strategically emigrated to major cities overseas to continue his ministry. Nee's books on spiritual life and biblical exposition are very popular in the unregistered house churches today. Most have been translated into English and are available on the website of the Living Stream Ministry. Nee's influence on the conservative churches in China cannot be overestimated.

Nee grew up in a Christian family but, as a young man, his faith was swayed by the intellectual arguments of the anti-religious movement of the time. After a dramatic conversion experience at school, however, he became enthusiastic about the experience of being filled by the Holy Spirit. Without formal theological education, he was deeply influenced by the French mysticism of Madame Jeanne de la Motte Guyon, by the dispensationalist view of G.H. Pember and Robert Govett and by the Holiness Movement of J. Penn-Lewis and Andrew Murray. His biblical interpretation was particularly shaped by C.A. Coats and J.N. Darby of the Brethren Movement in England (Lam 2003:21-29; Leung 2005)

Nee believed that all scripture was inspired by the Holy Spirit and was useful for teaching, for reproof, for correction and for training in righteousness (2 Tm 3:16). He therefore advocated the so-called lingyi jiejing ('spiritual interpretation'), which sought to unveil the spiritual meaning behind the words of biblical text (Leung 1997; Nee 1996:71-170). To find the spiritual meaning in biblical text, Nee urged readers to learn the whole Bible off by heart through the systematic investigation of the entire canonical context - as if eating, chewing and digesting spiritual food - to enable them to conduct a xitong chajing ('systematic investigation') into the fundamental themes of the Bible, to the extent that the parts would explain the whole and the whole would illuminate the parts. The idea of systematic investigation was similar to the interpretative principle of scriptura scripturum emphasised in the Reformed tradition and in the canonical approach, both of which assume an internal coherence among varied concepts in biblical books and a thematic unity in the entire canon intended by the Holy Spirit. Since the aim of biblical interpretation was to 'instruct' readers on matters of salvation so that they could be 'trained' to practise righteousness as spiritual people, the meaning of a text should be made clear to facilitate understanding. Thus, a minister of God's word, Nee insisted, needed to be inspired by the Holy Spirit to receive the light of revelation. It was then the minister's duty to translate the light of revelation into human thought that could be understood and, finally, to explain those thoughts in plain words (Nee 1996:171381).

Nee (1989.22) ranked Matthew as the most difficult book in the New Testament, stating that it was 'ten times more difficult than the Book of Revelation to understand'. He made three attempts to teach this Gospel in its entirety to his followers but was not, in any of these cases, able to finish it. ${ }^{3}$ In fact, it was

3.The first attempt was made in articles published In the Journal of Morning Star in Yentai, Shandong (Issue 220-239; Aug 1924-May 1926) which covers only the first two chapters of Matthew. These are published as Watchman Nee, Matal while he was teaching Matthew's Gospel in a training retreat at Guling Mountain, Fuzhou, that he was arrested and jailed. Nee later died in jail. His lecture notes at that retreat became the 'unfinished last sermons', which were later published with that title in Chinese. Three aspects from Nee's lecture notes were illustrative of his understanding of Matthew. These will now be discussed

\section{Jesus as saviour of the world}

Nee argued that one of Matthew's purposes in writing the Gospel was to show how Jesus, the messiah of the Jews, became the saviour of the world. Nee argued that, to suggest that Jesus' salvation was offered to both Jew and Gentile, Matthew referred to Jesus as the 'son of Abraham', through whom all nations would be blessed, and included four Gentile women in Jesus' genealogy; Jesus' salvific role was clearly indicated by his Hebrew name, 'Joshua', which means 'Yahweh is saviour' or 'Yahweh will save'. This was further expressed, Nee argued, in Jesus' title, 'Emmanuel', which means 'God and humans come together in him'. Since Jesus came to save his people 'from sins', Nee commented, the most serious problem that people faced, as Matthew saw it, was not the brutal oppression of the Roman Empire but the bondage of sin. In other words, Jesus was not a political liberator but a spiritual saviour. While commenting on Jesus' miracles (in Matthew 8), Nee reiterated that Jesus was the Son of God, which is why he could perform miracles. However, since there was no essential difference between someone who believed in the Lord because of miracles and someone who believed in demons because of the wonders that demons can do, the purpose of miracles was 'not so much to lead us to believe in God's power and wonders as to discern God's mind' (Nee 1989:138). God's mind was to save us from all sorts of sins and to share Jesus' new life.

This view of Jesus was categorically different from that held by Hong Xiuquan and his Taiping kingdom and reflected Nee's consistent warning about the power of sin and its relentless grip over human life. To explain why and how Jesus could save his people from $\sin$, Nee again referred to Jesus' title of 'Emmanuel', saying

Jesus can be the saviour [of sinners] because he is Emmanuel, that is, God and humans come together in him. Indeed, only in Emmanuel can there be salvation; otherwise, humans can never even touch God. In Jesus, humans and God have become one.

(Nee 1989:14)

For Nee, then, sin separated humans from God and salvation meant reconciliation with God made possible in Jesus. Nee also said the following:

The purpose of salvation is not to save and make a person perfect [in morality], but to make him saved. Even a [morally) perfect person remains a natural person, who cannot have a relationship of life with God. The mediator between God and humans is Jesus; and Emmanuel means God in Christ has reconciled with humans.

(Nee 1989:14)

For Nee therefore, the salvation that Jesus offered meant the forgiveness of sins and reconciliation with God and its purpose was to enable believers to enjoy a living relationship with God, not to make them morally perfect, as $\mathrm{Wu}$ Leichuan and other liberal scholars suggested.

\section{Jesus as teacher of Christian life}

Jesus saved his people from sin; he also taught them how to live a Christian life. It is interesting to note that Nee began his commentary on the Sermon on the Mount with the following disclaimer:

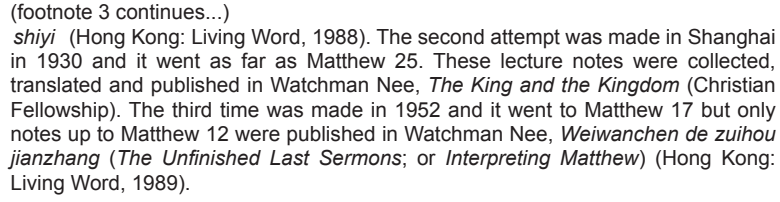
in 1930 and it went as far as Matthew 25. These lecture notes were collected, translated and published in Watchman Fellowship). The third 12 we was made in 1952 and it went to Matthew 17 but only notes up to Matthew 12 were published in Watchman Nee, Weiwanchen de zuihou jianzhang (The Unfinished Last Sermons; or Interpreting Matthew) (Hong Kong: Living Word, 1989) 
No sinner can be saved by obeying the teaching in the Sermon on the Mount. The Sermon on the Mount concerns not salvation, but Christian life. Christianity does not preach Christ's teaching to the sinners, but Christ's life.

(Nee 1989:60)

In other words, the Sermon on the Mount was given to Christians who were already saved to learn how to live a life worthy of God's grace. It was not given for the future millennial kingdom but for the present time. Every word of the Lord had to be obeyed in order to cultivate a Christian character. The Sermon on the Mount was not law, Nee also argued, because law in the Bible functioned to reveal our sinfulness. Rather, these high demands of Jesus' were challenging 'tests' meant to reveal the strength of our inner life. The more we are challenged to obey them, the more we learn to rely on God's power to fulfil them. Thus, Nee described the Beatitudes as seven personalities or temperaments that people of the heavenly kingdom should have in order to receive divine blessings. Because the Sermon on the Mount was intended to help Christians cultivate spiritual character, the commandment not to resist evildoers or to turn the other cheek should be understood as an intuitive Christian reaction to violence, which took the form neither of revenge nor of non-resistance but which completed self-emptiness. Because these teachings concerned individual Christian's characters, they should not be applied to political campaigns, social movements or national laws (Nee 1989:91-93). To find biblical teaching on political systems, one should consult Romans 13 instead of Matthew 5, Nee said (Nee 1989:94). To answer the question of whether the Sermon on the Mount was law or grace, Nee differentiated the idea of gift from that of reward:

Gift is what a sinner receives from God free of charge, whereas reward is what a person who has already received the grace of salvation will receive from God in the kingdom because of the good deeds that bring glory to God. Eternal life is absolutely granted by grace and faith, whereas the kingdom of heaven is absolutely received through reward and behaviour.

(Nee 1989:97)

\section{Concerns about spiritual life and final judgement}

In The unfinished last sermons (Interpreting Matthew), Nee's main purpose was exegetical, explaining to his followers Matthew's key concepts. However, because he understood the aim of reading scripture to be the acquisition of biblical instruction to pracitse righteousness, he often drew implications from Matthew's text to discuss issues of spiritual life. To give his audience specific advice, he added 'editorial notes' or 'sermon ideas' to his commentary. On the magi, for instance, Nee noted that, after seeing the star, the magi travelled to Jerusalem to enquire about Jesus and to learn about his birth place in Bethlehem with the help of scripture but that they finally found Jesus to worship him only when they followed the light of the star. Nee then added the following words to teach his followers how to find God's will:

Therefore, we need to discern the guidance from life situations, and the guidance from scriptural reading. Either one alone is not reliable, but both combined are much more reliable. When adding the guidance from the Holy Spirit to make three in one, it becomes the most reliable.

(Nee 1989:16-17)

On 'Do not judge so that you may not be judged' (Mt 7:1), Nee discussed the meaning of the Greek word for 'judge' and its Chinese translation and brought into discussion Romans 12 and 1 Corinthians 5:12 to explain that this concept meant not judging other people's motivation by one's own opinion. He developed the idea of judgement as follows:

The judgement that the Lord forbids is your inner feeling. Giving false witness can be a judgement. Telling truth can also be a judgement. If you allow your own feeling to be pleased but not to feel sorrowful, to blame but not to appeal for repentance, that is judgement.

(Nee 1989:120)
Nee had rich and deep spiritual experience in his life and was sensitive to spiritual struggles, which enabled him to address the subtle issues of human psychology and spiritual life. He argued, for instance, that the good tree that bears good fruit (Mt 7:17), referring to the words of the Lord in the Sermon on the Mount, as opposed to the words of false prophets. Citing Paul's teaching on the Holy Spirit bearing good fruit (Gal 5:22), Nee said, 'The real teaching is: the teaching of the Lord demands us to obey and then the Holy Spirit will bear fruit in us. Teaching plus Holy Spirit is the only way to bear fruit.' This statement illustrates Nee's intense interest in practical advice on spiritual life and his discussion of one scriptural idea in light of another (Nee 1989:129).

Again, when commenting on church leaders who were denied entrance to the kingdom of heaven (Mt 7:22), Nee included 1 Corinthians 12 and 14 in his discussion to warn charismatic Christians about the difference between spiritual fruit and spiritual gifts, one being spiritual life and the other being the ability for special tasks. He said, '[Spiritual] gift is not necessarily related to the inner (spiritual) life; it can help others' life [sic] but not one's own life.' (Nee 1989:130-131).

On the kingdom of heaven, Nee said that the Old Testament prophesied about its coming in the future. John the Baptist and Jesus then proclaimed that it had come near but that it would not be completely manifested until the millennial kingdom arrived. The church was therefore situated in between these periods. However, wherever there were children of God, there were already little kingdoms of heaven (Nee 1989:104-105). Hong Xiuquan had held a similar idea about the little kingdom of heaven or little paradise being realised in his Taiping kingdom. Nee, however, did not stop at a realised eschatology; he remained ever mindful of the future eschatology when the millennial kingdom would arrive and often used it as a guidepost to encourage spiritual progress. For Nee therefore, the Lord's Prayer was not a blueprint for the establishment of an ideal society, as Wu Leichuan had proposed; rather, it was a model prayer to teach Christians how to think in God's terms and how to ask for God's protection. On entering the narrow gate that led to life (Mt 7:13-14), Nee argued that the Sermon on the Mount was the narrow gate and that 'life' referred to the reward and the punishment that Christians would receive in the final judgement. Christians would surely be saved because of the grace of God in Christ but they would also be either rewarded or punished for their obedience or disobedience to Jesus' commandments in the Sermon on the Mount. The Sermon on the Mount was thus the norm of Christian life, with serious implication for the final judgement of Christians.

Nee's influence in the conservative circle was deep and wide. His 'spiritual interpretation', which sought to make spiritual meaning explicit by cross-referencing other biblical passages from the entire canon and by the association of words, symbols and themes, was evident in popular Chinese commentaries (Chen 1998). The effort to relate theological themes in the Bible to the aspects, stages and challenges of the spiritual life of readers was also evident in these commentaries. Even though Nee's interpretation may be in danger of 'eisegesis' or of 'personal ideas' slipping in (Lam 1985:287-288), its hermeneutics was 'not rule-less' (Leung 1997:45-46).

In summary, this study of the three interpretations of Matthew shows that 'saviour' and 'teacher' are two dominant Christological views in Chinese readings of Matthew. As a new religion recently imported to China, Christianity had to explain to Chinese people who it was that they believed in and worshipped. Naturally, Christology became the first question of concern in these interpretations of Matthew, besides the fact that Jesus was the subject matter of the First Gospel. Since other religious leaders were already revered and worshipped in China, Christian interpreters were compelled to justify not only Jesus' legitimacy but also his usefulness to Chinese people. 
Interpreters thus emphasised his role as the saviour who would save their nation, their society and their souls and his role as a supreme teacher who would teach them how to obey God's will to enable them to receive his blessings. Moreover, because Christianity arrived in China on the gunboat of imperial powers and at a time when the corrupt government had brutalised its people and lost credibility, Jesus' idea of the kingdom of heaven and his moral teachings, especially the Sermon on the Mount, were interpreted to provide vision, inspiration and guidance in efforts to address the national, moral and spiritual crisis.

\section{HERMENEUTICAL IMPLICATIONS}

The three interpretations of Matthew discussed demonstrate how highly Chinese Christians regard Matthew's Gospel and how seriously they try to apply its contents, Christology and moral teaching in particular to every aspect and level of both their personal and their community life. Chinese Christians read Matthew's Gospel not simply to satisfy their historical curiosity or to appreciate its literary artistry but also to look for doctrinal instruction and ethical guidance. As a minority group seeking acceptance in a multi-religious society with an anti-foreign atmosphere, Chinese Christians are compelled to relate with traditional culture. When they do not, as in Hong's case, their interpretation is rejected. Chinese Christians also shoulder the burden of proving how their Bible could be beneficial to Chinese society. When they can, as in Wu's case, their interpretation is well respected.

What can we learn about hermeneutical principles from these interpretations of Matthew? Recent Matthean scholarship in North America and Europe has focused its attention on 'the world of the text' and 'the world behind the text', using terms in the hermeneutic scheme by Schneiders (1999:97-179). Narrativecritical analysis of the first Gospel as literary text and sociological investigation of Matthew's church as sectarian community in reaction to the emerging pharisaic-rabbinic Judaism have been major forces in scholarly discourses in the past two decades. Some Chinese scholars trained in Western methodologies have adopted the same historical, redactional, narrative and sociological approaches to interpret Matthew's text, his church and his messages as communicated to the first readers with competence and proficiency (Chow 1984; Wong 1992; Yieh 2004). They still, however, face the challenge of 'translating' the results of their critical studies into understandable messages useful for their Chinese readers. Reading the Bible cannot be a mere academic exercise for Chinese Christians. We will now therefore look at 'the world before the text' to see what factors may have affected the way in which the three Chinese interpreters read and made sense of Matthew. Their hermeneutical process may be visualised in the following diagram and several observations are in order:

\section{- Hong Xiuquan:}

Visions: Reading Matthew as esoteric text $\rightarrow$ Christian kingdom versus demonic tyrants

- Wu Leichuan:

Reason: Reading Matthew as historical text alongside Chinese classics $\rightarrow$ Ideal society versus cultural corruption

- Watchman Nee:

Holy Spirit: Reading Matthew as revelatory text within the whole Bible $\rightarrow$ Spiritual life versus fleshly temptations

\section{Hermeneutical process and interpretative logic}

Hong Xiuquan, Wu Leichuan and Watchman Nee were all competent and perceptive readers of the Bible. Several personal factors contributed to their understanding of Matthew: their special life experiences (visions, reason or the Holy Spirit); their views of the nature of the Bible (esoteric, historical or revelatory); their frames of reference for reading (Matthew on its own, Chinese classics or the whole Bible) and the perceived crises at hand (oppressive tyranny, moral bankruptcy or fleshly temptations). Other factors also shaped their interpretation of Matthew, such as their theological tendencies (sectarian, liberal or dispensationalist), their interpretative purposes (political legitimation, social reform or spiritual training) and the conditions of their intended readers (citizens of the new kingdom, educated elites in universities or Christians in a spiritual training course). Many factors in the hermeneutical process and interpretative logic illustrated in these Chinese readings can also be found in Western interpretations, even though mainstream churches and biblical scholars in the West tend to look at conservative and literal readings of the Bible with suspicion and often shy away from the spiritual teaching and moral mandates of the Bible in a culture of disbelief. In this regard, Jenkins' general comment on African and Asian churches is also true of Chinese churches: 'As in the United States and Europe, global south churches produced a spectrum of theologies and interpretations. The north-south difference is rather one of emphasis' (Jenkins 2006:6).

Based on the three interpretations of Matthew that we have examined, we can identify four common Chinese emphases in biblical interpretation:

- A strong interest in Jesus' salvific and didactic roles rather than in his identities or titles

- A high reverence for the authority of biblical text and its claim on individuals, the society and the nation

- The aim of interpretation being to cultivate new Christian character, temperament and personality

- The final purpose being to improve spiritual life, to encourage moral behaviour and to benefit the whole nation.

As a matter of fact, these four emphases in biblical interpretation can be found in many other Chinese readers and preachers (Ji 1997:3-15). Chinese people have a long tradition of honouring sages as divinely gifted persons knowing heavenly will, natural order and human affairs. Time-tested classical texts were respected and studied because they consisted of valuable wisdom transcending history and useful foresight to help people to deal with the future (Leung 1997:43-44). Confucianism, among other traditions, indoctrinated all Chinese with the value of moral character as the essence of an authentic person and as the basis for building healthy families and a strong society. Underlying all these emphases was a Chinese pragmatic concern for life at the present time. Compared to Western scholars, who tend to keep a cognitive distance from the biblical world, these Chinese interpreters read the biblical texts with a 'fusing of horizons' because they believed that the Bible spoke directly to them. Such intimacy with the Bible may indeed have made them oblivious of historical and cultural gaps and misinterpret biblical meanings at times but it also brought them to a closer contact with biblical text in such a way that they were able to find some inner logic in the Bible and its existential claims on readers' lives. It should also be pointed out that there was tension between $\mathrm{Wu}$ Leichuan, who represented a liberal perspective, and Watchman Nee, who represented a conservative theological view. Is Matthew's Gospel a revelatory text or a cultural text? Is Jesus the saviour of a nation or of an individual soul? Is he a moral sage for social reform or a spiritual teacher of Christian life? Is Jesus' teaching meant for the nation to hear or for the church to obey? $\mathrm{Wu}$ and Nee gave contending interpretations of Matthew because there was a fundamental difference between their answers to these questions.

\section{Matthew's Gospel and Jesus' roles}

What did these Chinese interpreters have to say about Matthew's Gospel and Jesus that is noteworthy for Matthean scholarship in the West? They were all aware of Matthew's view of Jesus as the Messiah of the Jews and the Son of God, as Western scholars (such as W.D. Davies and J.D. Kingsbury) have long argued. Compared to most Western scholars, however, they took a keener interest in what Jesus did than in who Jesus was. They thus explained and argued how Jesus played the role of the mighty saviour of the world and/or as the supreme teacher 
of God's will. It was on Jesus' role and function, rather than his titles and identities, that they found a point of contact between Matthew's Jesus and Chinese people in crisis.

Thus, Hong Xiuquan found Jesus to be the mighty saviour who saved his people from the 'demonic' tyranny of the Qing dynasty and, because of his power as saviour, his commandments were considered divine laws to be strictly enforced in the Taiping kingdom. Wu Leichuan honoured Jesus as the wise sage whose personal example and moral teachings inspired his followers to reform their moral character and build an ideal society for the new China; Jesus the teacher was thus also the saviour of Chinese culture. Watchman Nee regarded Jesus as the saviour of human souls from sin and his teaching therefore provided divine guidance for the spiritual progress of Christian life. One may disagree with specific points of these interpretations but, as spotlights, they each highlighted one important aspect of Jesus' role as saviour and/or teacher. While focusing on Jesus' salvific or didactic roles to address political, social or spiritual crises, together they revealed a surplus of meanings in Matthew's Christology that provided rich resources to be appropriated for each new situation faced by the Chinese church. Moreover, in their appropriations of Matthew's Jesus and his teachings, we see remarkable examples of indigenisation and contextualisation efforts with both positive and negative consequences for the life of the church in China.

The confidence and boldness that Hong and $\mathrm{Wu}$ demonstrated in connecting the Christian Bible with Chinese culture and in applying Jesus' teachings to society and nation-building were amazing. Furthermore, the firm conviction that Nee showed in his unfailing attention to the reality of the final judgement and to the need of Christians to pursue righteousness beyond faith brought out Matthew's eschatological horizon and stern warning about readiness in a way rarely seen among biblical scholars in the West.

We are thus reminded, as Luz (1994:20) strongly urged, of the importance of faithfulness as an exegete in seeking the 'kernel of meaning' within the grammatical-historical structure of biblical text in its first contexts and of the necessity of openness as an interpreter in discerning the 'directional meanings' that the theological-ethical implications of biblical text may continue to yield to help us address new life situations.

\section{Cross-cultural reading and post-colonial criticism}

Finally, what do these three interpretations of Matthew say about cross-cultural reading and post-colonial criticism that has caught scholarly attention in recent years? Given their particular historical contexts, these three Chinese interpreters represented early-colonial, colonial and post-colonial readings of Matthew.

\section{Christian Bible and Chinese culture}

Chinese Christians are often caught in a head-on clash between the Christian Bible and Chinese culture, both of which have deeprooted world views, value systems, spiritual expectations and moral demands. Reading the Bible is a cross-cultural journey, at the end of which no traveller can escape change. Is it possible for a Chinese reader to be loyal both to the Christian Bible and to Chinese culture? Is it possible for the biblical world and the Chinese world to be reconciled with authenticity and integrity? In the three examples that we examined in this paper, we find three modes of cross-cultural reading:

- Hong Xiuquan seemed to believe that biblical revelation should replace Chinese culture, which was full of superstition and idolatry. After his conversion and in his military campaigns, he therefore destroyed numerous Buddhist temples wherever his army passed and he gave orders to burn Confucian classics in Nanking. In the early-colonial period in China, when the Christian Bible encountered Chinese culture for the first time, such radical and iconoclastic actions demonstrated the powerful impact that the Christian Bible exerted on Hong. He may also have felt disillusioned with Chinese culture because he witnessed the selfish, hypocritical and corrupt behaviour of many Confucian scholars and government officials of the Qing dynasty.

- In comparison to Hong, Wu Leichuan held a more positive view of Chinese culture. In the encounter between the Christian Bible and Chinese culture, $\mathrm{Wu}$ believed that traditional Chinese culture could be fulfilled and improved by the moral teachings of the Bible. Chinese culture remained an important heritage and asset of Chinese Christians and it could help them to understand and preach the Bible to other Chinese. At a time when Western colonial power had made inroads into China and had established universities, $\mathrm{Wu}$ 's relative confidence in Chinese culture and critical appreciation of the Bible showed a measured understanding of this cultural clash. In his reading of the Bible, he showed a critical appreciation both of Western liberal theology and of Chinese moral tradition.

- In contrast to Wu, Watchman Nee made no explicit attempt to connect Chinese culture with the Bible in his interpretation of Matthew. His Reformed understanding of human sin may have led him to see mostly depravity in human culture and his dispensational view of history, which awaited Judgement Day, may have led him to seeing nothing but the Bible as the revelatory text of God for eventual salvation.

In all three modes of cross-cultural reading (replace, fulfil and ignore), fresh insights can be found.

\section{Bible reading and colonial discourses}

In a provocative essay written for $A$ postcolonial commentary on the New Testament writings (2007:69-104), Carter embarks on a reading of Matthew's narrative and Matthew's theology from a post-colonial perspective and brilliantly shows how Matthew's Gospel reflects a lived imperial experience on the margins, attesting both modes of subjugation and modes of resistance in an oppositional yet co-opted text'. What may be puzzling is that, while resisting the all-pervasive influence of the Roman Empire, Matthew also imitated the strategies of the Empire when he presented Jesus as asserting his authority over heaven and earth and as announcing the rule of God's kingdom with enticing blessings and threats of judgement. If one objects to any form of imperial power, Matthew's blatant 'imperial' discourse may become a troublesome question. Carter therefore calls for a critical review of Matthew's 'imperial' theological assumptions and urges his readers to trust in God's mercy even in the final judgement.

Whereas Carter reads Matthew's Gospel with a post-colonial, anti-imperial critique, we may briefly look at the way in which our three Chinese interpreters interacted with the imperial powers of their times. It may be helpful to bear in mind that, as converts to a foreign religion, Chinese Christians are often accused of 'cultural treason' by believers of the traditional religions of Buddhism, Taoism and Confucianism. They are regarded as counter-cultural because religious conversion means not only a changed mind but also a changed way of life. When Christians refuse to participate in ancestor worship (a traditional ritual to express filial piety and consolidate familial relationship) or other religious festivals in honour of local gods and goddesses (customary ways to strengthen communal unity), they are condemned for their 'anti-social' behaviour and, as a result, are sometimes harassed or persecuted. There was a tragic precedent, for example - the Rites Controversy - that took place in the 17th century between the popes in Rome and the Chinese emperors, which resulted in the ban of Catholic missions and the horror of religious persecution.

How then did these three Chinese interpreters of Matthew deal with missionary influences and colonial powers of their times? Did they assert their Chinese cultural identity or show any of the anti-imperial tendencies that recent post-colonial criticism is concerned about? 
It is interesting to note that Hong Xiuquan led his Taiping forces against the Qing rulers, calling them barbarian rulers, but that he sought cooperation with foreign imperial powers (the English, American and French naval dispatches in Shanghai) because he thought that they shared the same Christian faith with him, while the Qing dynasty was regarded as the demonic 'imperial power' that should be eradicated. Hong believed that all peoples were children of God and that Christianity transcended politics. However, in establishing the Taiping heavenly kingdom, he mimicked every form of imperial manoeuvre and strategy to take power and control. He did, in fact, simply replace the Qing Empire with a quasi-Christian empire of his own, equally corrupt and oppressive. This became one of the reasons why his kingdom failed.

Wu Leichuan lived through a time in the modern history of China when foreign aggression and colonial attempts were at their height. He was, however, able to turn inward for selfexamination and choose moral persuasion instead of empire-like coercion to advocate an ideal society. Wu wanted to save China from imperial exploitation but was wise enough to combine what was good from both imperial influence (such as reason and science) and Chinese tradition (such as moral character and concern for the community), perhaps because he had seen the benefit of missionary enterprise in education, medicine and social service as well as the arrogant abuse of Western traders and diplomats. He was therefore able to transform imperial discourse and pursue a moral discourse.

Finally, Watchman Nee, who was active throughout colonial and post-colonial times, did not react to any particular imperial ideology and was able to resist the power of domination, perhaps because his church had been a self-governing, self-supporting, self-propagating independent church from the start and because he focused his ministry on training Christians to grow mature spiritually in preparation for the final arrival of God's kingdom. In his interpretation of Matthew, he sought to transcend the colonial discourse of power to travel into a new spiritual world.

Again, in very different approaches to the colonial reality, some insights can be found. The validity and value of an interpretation should, in the final analysis, be assessed in terms of coherent arguments and positive consequences.

\section{CONCLUSION}

We have paid a short visit to three Chinese colleagues who loved Matthew and who revered Jesus both as saviour and as teacher. They tried to make sense of Jesus and his teachings for themselves and for Chinese people as they were experiencing radical social changes and national crises. Their interpretations of Matthew were unapologetically contextual because they wished to use scripture to address the crises confronting them and to lead and guide their Chinese readers to walk in the way of the kingdom of heaven. I hope that this imaginative crosscultural visit has raised some interesting questions for us all that inspire us to read Matthew's Gospel once again from a different angle and to continue to converse about Jesus and his teachings with Chinese interpreters and with others who live in different cultural settings.

\section{REFERENCES}

Carter, W., 2007, 'The Gospel of Matthew', in F.F. Segovia \& R.S. Sugirtharajah (eds.), A postcolonial commentary on the New Testament writings, pp. 69-104, T \& T Clark, New York.

Chan, S-W. \& Pollard, D.E. (eds.), 1995, An encyclopedia of translation, The Chinese University Press, Hong Kong.

Chen, D-X., 2005, 'Jesus, the incarnation of universal love', in R. Malek (ed.), The Chinese face of Jesus Christ, vol. 3, pp. 1208 1214, Sankt Augustin, Nettetal.

Chen, S.C.T. (Chen Zhongdao), 1998, The King of heaven: Commentary on Matthew, rev. edn., China Alliance Press, Hong Kong.

Choong, C-P. (ed.), 1997, The role and interpretation of the Bible in the life of the Church in China, The Lutheran World Federation, Geneva.
Chow, D.T-W., 1984, Shanshang baoxun de yanjiu [A study of the Sermon on the Mount], Taosheng, Hong Kong.

Chow, T-T., 1960, The May fourth movement: Intellectual revolution in modern China, Stanford University Press, Stanford.

Chu, S-J., 1995, Wu Leichuan: A Confucian-Christian in republican China, Peter Lang, New York.

Ding, G-X., 2000, Lun Jidu [On Christ], China Christian Three Self Patriotic Movement Committee and China Council of Churches, Shanghai.

Fairbank, J. (ed.), 1975, The missionary enterprise in China and America, Harvard University Press, Cambridge.

Hong, X-Q., 1853, Qinding qianyizhao shengshu (Ch'in-ting ch'ien-ichao sheng-shu; The sacred book of the formerly bequeathed oracles [former testament] annotated by his Royal Majesty), 8 vols. (3rd vol. missing), n.p., Nanking.

Jenkins, P., 2006, The new faces of Christianity: Believing the Bible in the global south, Oxford University, New York.

Jenner, T., 1911, The Nanking monument of the beatitudes, William Clowes \& Sons, London.

Ji, T., 1997, 'Hermeneutics in the Chinese Church', in C-P. Choong (ed.), The role and interpretation of the Bible in the life of the Church in China, pp. 3-15, The Lutheran World Federation, Geneva.

Kingsbury, J.D., 1975, Matthew: Structure, christology, kingdom, Fortress Press, Philadelphia.

Kinnear, A.I. (ed.), 1968, The normal Christian life, Christian Literature Crusade, Fort Washington.

Kinnear, A.I., 1974, Against the tide: The story of Watchman Nee, Victory, Eastborne.

Lam, W-H., 1985, The spiritual theology of Watchman Nee, China Theological School of Theology, Hong Kong.

Lam, W-H., 2003, Shuling shenxue: Neetuosheng sixiang de yanjiu [The spiritual theology of Watchman Nee], China Alliance, Hong Kong.

Leung, K-L., 1997, 'A defense for spiritual interpretation of the Chinese Church', in C-P. Choong (ed.), The role and interpretation of the Bible in the life of the Church in China, n.p., The Lutheran World Federation, Geneva.

Leung, K-L., 2005, Watchman Nee: His early life and thought, Graceful House, Hong Kong.

Luo, E-G. \& Wang, Q-C. (eds.), 2004, Taiping tianguo, 10 vols., Guangxi Shifan Daxue, Guilin.

Loh, I-J., 1995, 'Chinese translations of the Bible', in S. Chan \& D.E. Pollard (eds.), An encyclopedia of translation, p. 55, The Chinese University Press, Hong Kong.

Luz, U., 1994, Matthew in history: Interpretation, influence, and effects, Fortress Press, Minneapolis.

Luz, U., 2005, Studies in Matthew, Eerdmans, Grand Rapids.

Malek, R., 2004, Verschumerlzung der Horizonte: Mozi und Jesus; Zur Hermeneutik der chinesisch-christlichen Begegnung nach Wu Leichuan (1869-1944), Brill, Leiden.

Michael, F. (ed.), 1966, The Taiping rebellion: History and documents, 3 vols., University of Washington Press, Seattle.

Nee, W., 1930, The king and the kingdom, Christian Fellowship, Shanghai.

Nee, W., 1968, The spiritual man, 3 vols., transl. S. Kaung, Christian Fellowship, New York.

Nee, W., 1988, Matai shiyi, Living Word, Hong Kong.

Nee, W., 1989, Weiwanchen de zuihou jianzhang [The unfinished last sermons; or Interpreting Matthew], Living Word, Hong Kong.

Nee, W., 1996, Shen de huayu de zhishi [The normal Christian preachers], Christian Publishers, Hong Kong.

Schneiders, S., 1999, The revelatory text: Interpreting the New Testament as sacred Scripture, Liturgical, Collegeville.

Segovia, F.F. \& Sugirtharajah, R.S. (eds.), 2007, A postcolonial commentary on the New Testament writings, T \& T Clark, New York.

Spence, J., 1996, God's Chinese son: The Taiping heavenly kingdom of Hong Xiuquan, Norton, New York.

Spence, J., 1998, The Taiping vision of a Christian China 1836-1864, Markham, Waco. 
Wagner, R., 1982, Reenacting the heavenly vision: The role of religion in the Taiping rebellion, Institute of East Asian Studies, UC Berkeley.

West, P., 1974, 'Christianity and nationalism: The career of Wu Lei-ch'uan at Yenching University', in J. Fairbank (ed.), The missionary enterprise in China and America, pp. 226-246, Harvard University Press, Cambridge.

Wong, E.K-C., 1992, Interkulturelle Theologie und Multikulturelle Gemeinde im Matthäusevangelium - Zum Verhältnis von Juden - und Heidenchristen im ersten Evangelium, NTOA 22, Universitätsverlag, Vandenhoeck \& Ruprecht, Freiburg, Göttingen.

Wu, L-C., 1924a, 'Duiyu zai zhishijie xuanchuan jidujiao de wojian' [An opinion on evangelism among the intelligentia], Shenmingyuekan 5(1), n.p.

Wu, L-C., 1924b, 'Zongjiao bianhuoshuo' [On discerning religion], Zhenlizhoukan 2(30), n.p.
Wu, L-C., 1925, 'Tianguo shi shemo?' [What is the kingdom of heaven?], Zhenlizhoukan 3, 9.

Wu, L-C., 1931, 'Yesu xinshehui de lixiang ji qi shixian de wenti' [The ideal and practice of Jesus' new society], Zhenliyushenming banyuekan 6,1 .

Wu, L-C., 1936, Jidujiao yu zhongguo wenhua [Christianity and Chinese culture], Youth Association, Shanghai.

Wu, L-C., 1950, Modi yu yesu [Motze and Jesus], (2)30, n.p. Youth Association, Shanghai.

Wu, Y-Z., 1936, 'Preface', in L-C. Wu (ed.), Jidujiao yu zhongguo wenhua (Christianity and Chinese Culture, n.p., Youth Association, Shanghai.

Wu, Y-Z., 2005, 'My conception of the universe and of life since I knew Jesus', in R. Malek (ed.), The Chinese face of Jesus Christ, vol. 3, pp. 1236-1241, Sankt Augustin, Nettetal.

Yieh, J., 2004, One teacher: Jesus' teaching role in Matthew's gospel report, Walter de Gruyter, Berlin. 